Ann. Biol. anim. Bioch. Biophys., 1978, 18 (4), 1027-1034.

\title{
Studies on the rainbow trout (Salmo gairdneri Rich.). I. Correlation between gonadal development and serum protein pattern
}

\author{
par B. BORCHARD
}

Landesanstalt für Fischerei NW, 5942 Kirchhundem 1, West Germany.

\begin{abstract}
Summary. Maturity was studied on 273 rainbow trout of both sexes. The female gonads were classed into 3 maturation stages and the male gonads into 4 . Characteristic pherograms of both serum protein electrophoresis and total serum protein corresponded with maturation stage. Electrophoretic globulin and total protein fractions increased considerably with spermatogenetically active testes and mature ovaries; the $A / G$ ration decreased accordingly. These parameters can be used to determine maturity.
\end{abstract}

\section{Introduction.}

Several reports have been published on the serological parameters of fish. The general serology of rainbow trout has also been studied (Perrier et al., 1973, 1974, 1976; Saifi, 1969, Delcroix, 1972). The serum protein pattern has been shown to be affected by diseases (Riedmüller, 1971), toxic substances (Thurston, 1967) and seasonal variation such as water temperature (Schlotfeldt, 1975). Haider (1970) has reported pherogram differences according to age. Considerable work has been carried out on female fish indicating that specific female proteins occur in the blood during gonad maturations (Drilhon and Fine, 1963 ; Thurston, 1967). The present study was done to determine if there are also changes in serum protein during testis growth. The gonads were classed according to maturation stage and the serum protein pattern changes occuring at different stages of testis and ovary maturation were noted.

\section{Material and methods.}

Rainbow trout of one and the same group were used. From October 1975 to May 1977, blood samples were taken from 168 spawning fish (medium length : $35.1 \mathrm{~cm}$; medium weight : $477.4 \mathrm{~g}$; age : 31 to 50 months) and 95 fingerlings (medium length: $23.4 \mathrm{~cm}$; medium weight : $98.1 \mathrm{~g}$; age : 8 to 20 months). Ten rainbow trout of a different group from another pond were used as controls. Blood samples were usually taken once a week from all the 273 fish by cardiac puncture (Lehmann and Stürenberg, 1974). This fechnique required the use of a holder. The unanesthetized fish 
was held down and a sterile needle (Supra Rekord Typ M, $40 \mathrm{~mm}$ long, $1.40 \mathrm{~mm} \varnothing$ ) injected carefully and nearly vertically through the skin exactly between the pectoral fins into the heart ventricle. Immediately after the needle penetrated the cardiac wall, the blood was withdrawn drop by drop with the heartbeats. After the first 2 drops were discarded, the blood was collected in a small glass tube. Each sample was stored for $10 \mathrm{~min}$. at $4{ }^{\circ} \mathrm{C}$ to allow clotting; it was then centrifuged at $5000 \mathrm{~g}$ for $10 \mathrm{~min}$. Only the serum of sound fish was fractionated; some was used at once for analysis, and the rest was deep-frozen at $-80^{\circ} \mathrm{C}$ for further utilization. Several organs were excised for further study.

Electrophoresis. - Micro-electrophoresis on cellulose acetate strips (Boskamp) was used to separate the serum proteins. In preliminary experiments the usual method of electrophoresis on cellulose acetate was modified. The optimal separation was reached at a running time of 24 min., voltage 250 , Michaelis buffer at $\mathrm{pH} 8.5$; strip staining was done with amido black staining liquid. Pherogram quantity was evaluated with an automatic pherostat (Super Cellomatic, CELTEC).

Determination of total protein and albumin. - The total serum protein of each trout was analysed. We used a modified Biuret method (Weichselbaum, 1946) with $20 \mu \mathrm{l}$ serum and $2 \mathrm{ml}$ Biuret reagent. With copper salts the proteins formed a stained complex ; the staining intensity of this complex was proportionate to protein concentration and was determined photometrically. For hyperlipemic or hemolytic serum, we subtracted blank-value absorbance from that of the Biuret complex.

Albumin was analyzed photometrically using the Bromocresol blue technique (Schirardin and Ney, 1972). This works very well with human serum, but with fish serum the values may differ from those obtained with electrophoresis, especially when hyperlipemic serum is involved. Nevertheless, with this technique a protein fraction can be classed as an albumin or a globulin. Further mention of « albumin 》 « globulin » or the « albumin-globulin $(A / G)$ ratio » in this report must be regarded as limited since we did not exactly identify the single protein fractions during this study.

Quality control. - A definite human control serum and a self-made serum pool consisting of about 200 rainbow trout serums were used for control of integrity and precision. This quality control was carried out for the electrophoretic and photometric determinations. Statistical variations were in the range of \pm 2.5 .

Hisfological preparation. - The gonads were fixed in Bouin solution and embedded in paraffin. The 6 to $8 \mu$-thick sections were stained using the Aldehyde-FuchsinGoldner method.

\section{Results.}

\section{Gonad maturation stages.}

The ovaries were divided into 3 stages:

Stage I : ovary with small, immature eggs ; zona radiata and yolk mass not present ; Stage II : nearly maiure eggs with yolk, shortly before ovulation ; follicular epithelium and zona radiata already entirely developed ; 


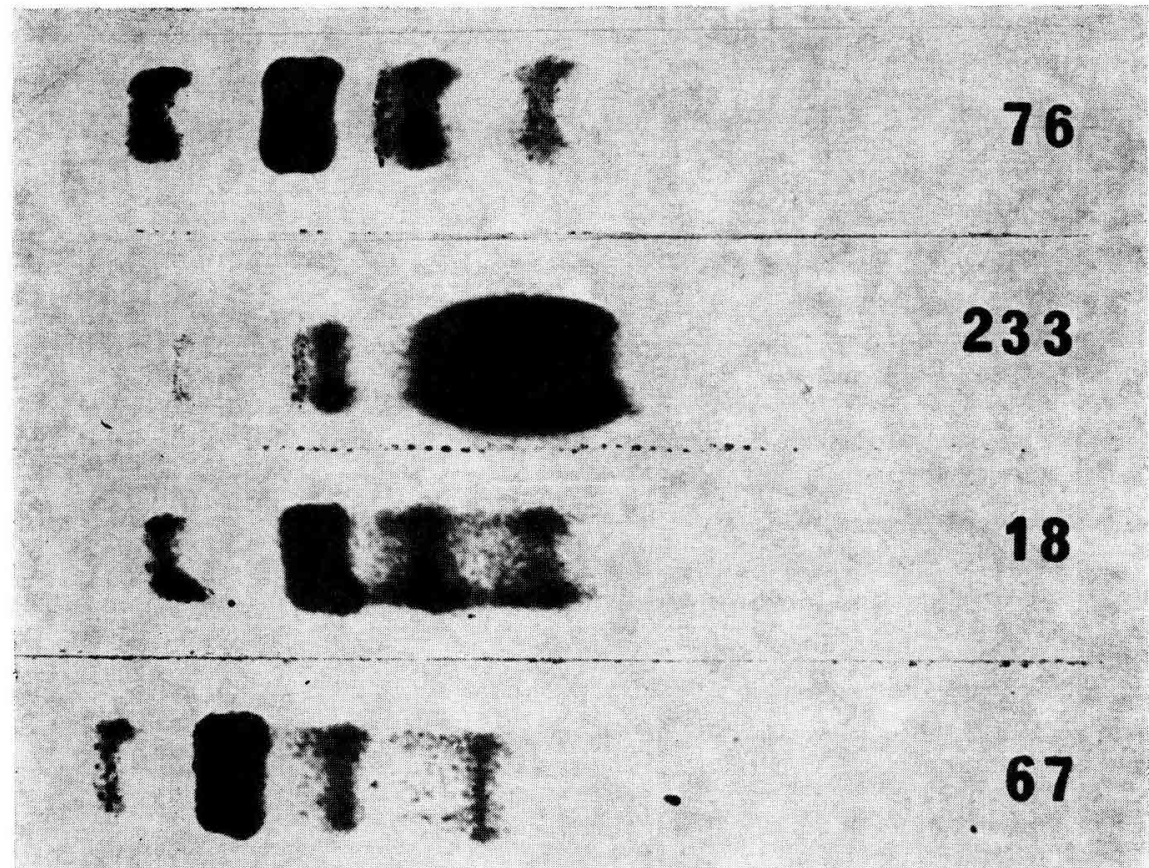

FIG. 1. - Electrophoretic pherograms of male trout. 76 : maturation stage I ; 233 : maturation stage II ; 18 : maturation stage III ; 67 : maturation stage IV.

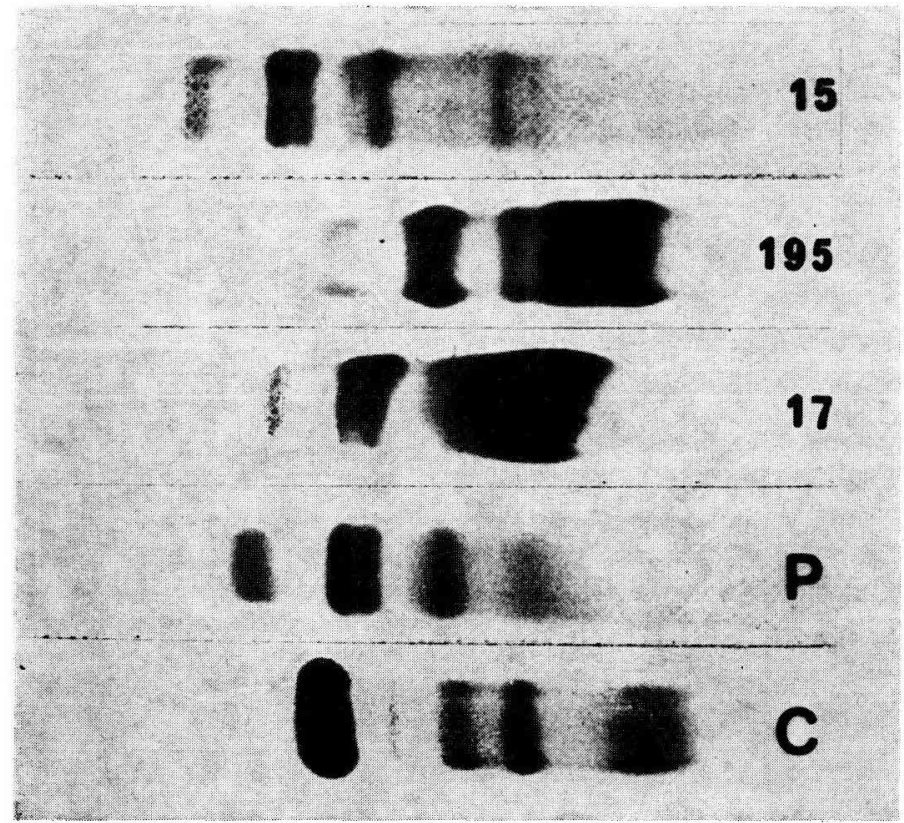

FIG. 2. - Electrophoretic pherograms of female trout. 15 : maturation stage $1 ; 195$ : maturation stage II ; 17 : maturation stage III ; C : human control serum ; P : serum pool of 200 rainbow trout. 
Stage III : mature eggs with big yolk mass lying free in the coelom ; follicular cells already discarded.

The testes were classified into 4 maturation stages :

Stage I : juvenile testis with small tubules not yet clearly separated ; interstitium only weakly developed ;

Stage II : testis at onset of spermatogenesis ; tubule diameter and interstitium highly enlarged ;

Stage III : nearly mature testis with highly enlarged inferstitium and fubules with spermatogonia, spermatocytes and spermatozoa in the lumen ;

Stage IV : mature testis with no new formation of spermatozoa ; tubule lumina filled with mature sperms.

\section{Electrophoresis.}

Differences corresponding to maturation stages appear in the pherograms of male and female fish. Figures 1 and 2 show the pherograms of some subjects at different stages of maturity. The strong increase of the protein fractions in fishes 233 (fig. 1), 195 and 17 (fig. 2 ) is especially evident.
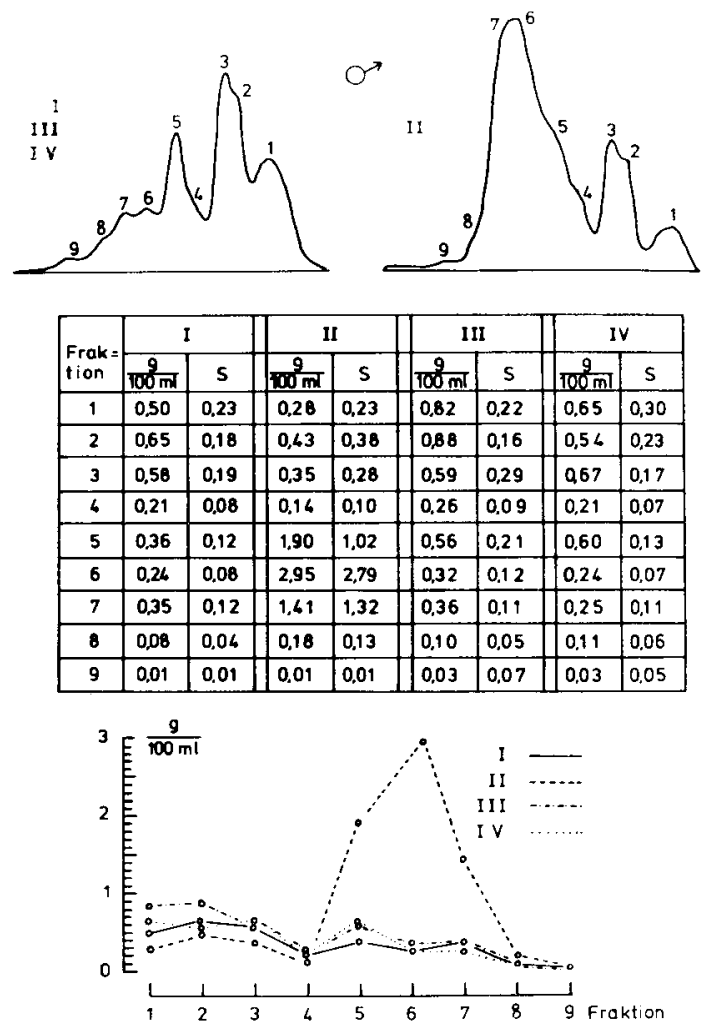

FIG. 3. - Integral graphs showing pherograms, average means, standard deviations ; graphs of single protein fractions of male rainbow trout at maturation stages $I, I I, I I I$ and $I V$. 
As single protein fractions have not yet been characterized biochemically, they are indicated by numbers 1 to 9 , corresponding to decreasing mobility. The integral graphs and the table of figure 3 show that there are no differences in maturation stages I, III and IV in the males. In maturation stage II the fractions 5, 6, and 7 quantitatively increase sharply. The same may be said of the female animals (fig. 4) in which protein fractions 5, 6 and 7 increase strongly with advancing maturity.

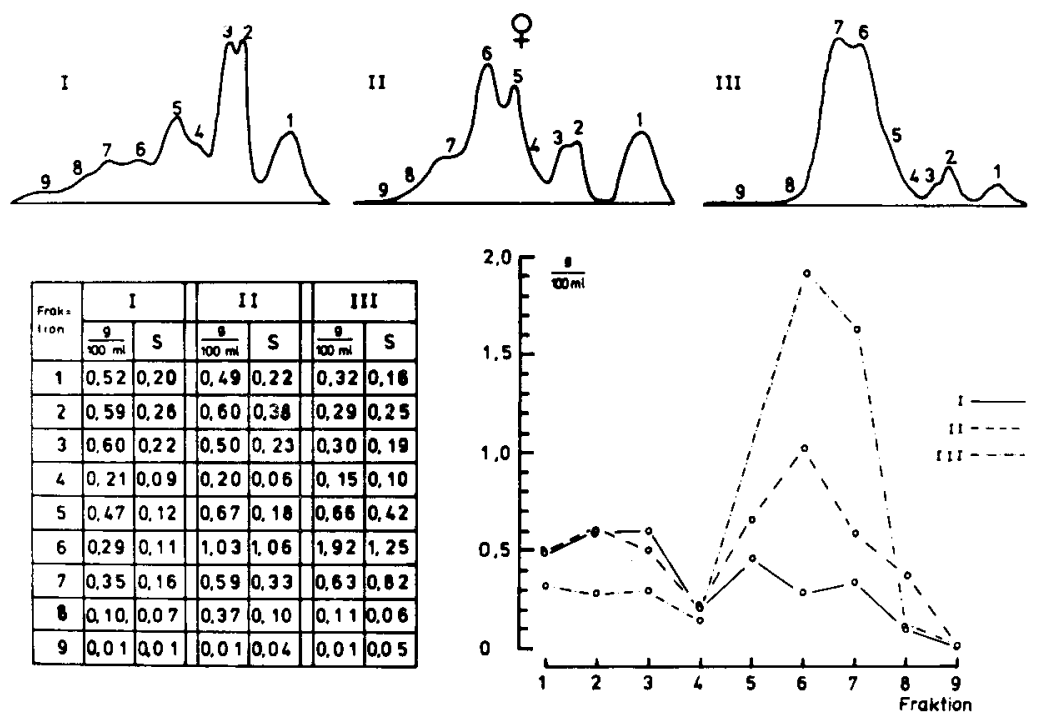

FIG. 4. - Integral graphs showing pherograms, average means, standard deviations ; graphs of single protein fractions of female rainbow trout at maturation stages I, II and III.

Total protein, $A / G$ ratio and gonad weight.

The total protein rise with progressive maturity from a mean of $3 \mathrm{~g} \mathrm{p} .100$ to $5 \mathrm{~g}$ p. 100 in the females (fig. 5). In the males there is a clear maximum of $7.5 \mathrm{~g} \mathrm{p.} 100$ at maturation stage II, while the values of the other maturation stages lie between 3 and $4 \mathrm{~g}$ p. 100.

A comparison of the photometric albumin analysis with the electrophoretic values shows that the protein infractions 1,2 and 3 must be albumins. The A/G ratio was ascertained accordingly. This ration is graphically the reverse of total protein (fig. 5). Gonad weight also increases with maturation.

\section{Discussion.}

Electrophoretic and total protein fractions in the serum of male and female rainbow trout change with the stage of gonadal maturation. During this process the total protein increases in stage II males; this increase mainly results from an increase of serum protein electrophoretic fractions 5,6 and 7 which are globulins. The A/G ratio decreases accordingly at maturation stage II. This maturation stage is characterized 
ㅇ
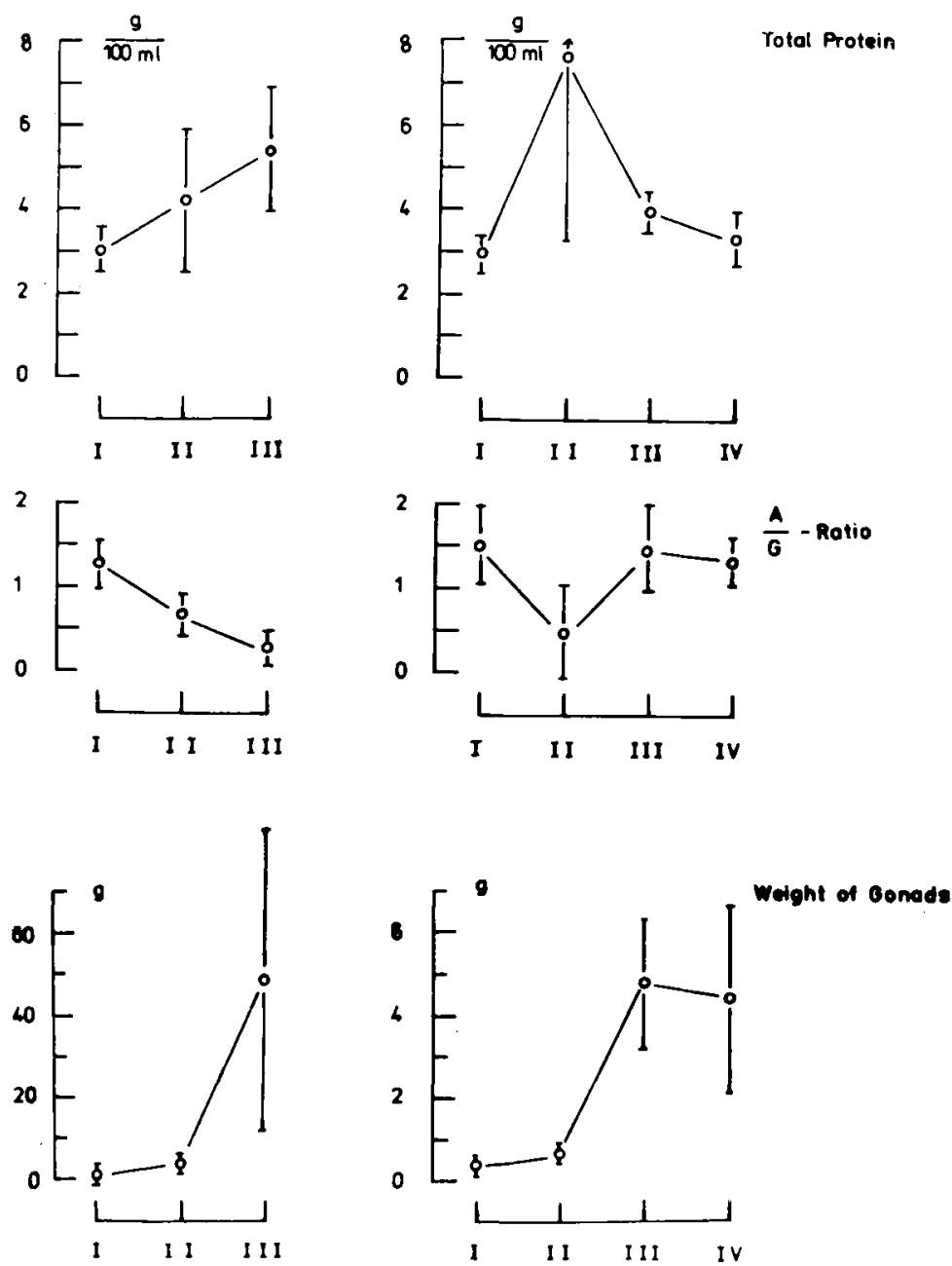

FIG. 5. - Graphs showing total protein, $A / G$ ratio and weight of male (right) and female (left) gonads at maturation stages I, II, III and IV and I, II and III, respectively.

by strong spermatogenic activity and increased tubule diameter. Large quantities of building material are probably necessary for testicular synthesis and the development of spermatocytes and spermatozoa ; this material is transported in the blood to the testis as a protein of globulin fractions 5, 6 and 7. However, only little or no building protein is needed if spermatogenic activity is weak (maturation stage III), or if the testes have mature sperms (maturation stage IV). These differences found in the serum protein of male trout during spermatogenesis have not been previously reported by other workers. 
Conditions are slightly different in the female fish. The gonadal products are not formed over a short period and stored in the gonads until spawning time. On the contrary, the maturation of ovary and eggs, and especially yolk accumulation, continue over a longer interval. Accordingly, during maturation stages II and III, the total protein and globulin fractions 5, 6 and 7 are high as they are probably precursors of yolk protein. These results in female trout serum are comparable to those found by Thurston (1967) and Drilhon and Fine (1963) who reported a special protein fraction in the serum of mature females.

It is also evident that the pherograms of immature adult fish do not differ from those of fingerlings. Therefore, there are no age differences in any parameters studied, as described by other authors (Haider, 1970) ; the differences only reflect maturation stages.

As this is a preliminary study, the results will be confirmed with other parameters, and the separated electrophoretic fractions will have to be defined by physicochemical characters.

Symposium sur la Reproduction des Poissons Paimpont, France, 19-21 septembre 1977.

Acknowledgments. - Research was sponsored by the State Government of NordrheinWestfalen.

Résumé. La maturiłé sexuelle a été étudiée sur 273 truites Arc-en-ciel des deux sexes. Les gonades femelles ont été classées en 3 stades de maturation et les gonades mâles en 4 stades. Les caractéristiques de l'électrophorègramme des protéines sériques identifiées par électrophorèse et les protéines sériques totales correspondent aux stades de maturation. Les globulines électrophorétiques et des fractions de protéines totales augmentent considérablement avec l'activité spermatogénétique des testicules actifs et la maturité des ovaires ; le rapport $A / G$ décroît parallèlement. Ces paramètres peuvent être utilisés pour déterminer la maturité.

\section{References}

DELCROIX J.-P., 1972. Ełude analytique des composés protéiques du plas ma de d'élevage (Salmo gairdnerii Richardson). Thèse Doct. Univ. Pharm., Lyon.

arc-en-ciel

DRILHON A., FINE J. M., 1963. Dimorphisme sexuel dans les protéines sériques de Salmo salar : Etude electrophorétique. C. R. Soc. Biol., 157, 1897-1900.

HAIDER G., 1970. Alters- und saisonbedingte Veränderungen im Serumeiweissbild der Regenbogenforelle (Salmo gairdneri Rich.). Z. Fischerei NF., 18, 107-124.

LEHMANN J., STÜRENBERG F.-J., 1974. Haematologische-serologische Substratuntersuchungen an der Regenbogenforelle (Salmo gairdneri Richardson). Gewässer und Abwässer, 53/54, 114-132.

PERR IER H., DELCROIX J.-P., PERRIER C., GRAS J., 1973. An attempt to classify the plasma proteins of the rainbow trout (Salmo gairdnerii Richardson) using disc electrophoresis, gel filtration and salt solubility fractionation. Comp. biochem. Physiol., 46B, 475-482.

PERRIER H., DELCROIX J.-P., PERRIER C., GRAS J., 1974. Disc electrophoresis of plasma proteins of fish. Physical and chemical characters ; localization of fibrinogen, transferrin and ceruloplasmin in the plasma of the rainbow trout (Salmo gairdnerii Richardson). Comp. biochem. Physiol. 498, 679-685.

PERRIER H., PERRIER C., DELCROIX J.-P., BORNET H., GRAS J., 1976. Study of the iodide binding protein of the plasma of the rainbow trout (Salmo gairdnerii Richardson). Comp. biochem. Physiol., 55A, 165-167. 
RIEDMÜLLER S., 1971. Elektrophoretische Serumeiweissuntersuchungen an Karpfen, 70-89. In LIEBMANN H., Die infektiöse Bauchwassersuchf (IBW) der Karpfen. R. Oldenbourg Verlag, München.

SAIFI Q., 1969. Etude qualitative ef quantitative des protéines sériques ef musculaires chez la truite arcen-ciel d'élevage. (Salmo gairdnerii Richardson.) Thèse Doct. Univ. Pharm., Lyon.

SCHIRARDIN H., NEY J., 1972. Eine vereinfachte Mikromethode zur Bestimmung von Serumalbumin mił Hilfe von Bromkresolgrün. Z. klin. Chem., 10, 338-344.

SCHLOTFELDT H. J., 1975. Nachweis jahreszeitlicher Schwankungen des Serumeiweissbildes der Regenbogenforelle (Salmo gairdneri Rich.) mit Hilfe der Celluloseacetatfolien-Elektrophorese. Zbl. Vet. Med. B, 22, 113-129.

THURSTON R. V., 1967. Electrophoretic patterns of blood serum proteins trom rainbow frout (Salmo gairdneri). J. Fish Res. Bd Can., 24, 2169-2188.

WEICHSELBAUM T. E., 1946. An accurate and rapid method for the determination of proteins in small amounts of blood serum and plasma. Am. J. clin. Path., 10, 40. 